$\sqrt{B}$

J. Bio-Sci. 27: 83-88, 2019

ISSN 1023-8654

http://www.banglajol.info/index.php/JBS/index

DOI: https://doi.org/10.3329/jbs.v27i0.44673

\title{
ANTIBACTERIAL AND CYTOTOXIC ACTIVITY OF TAMARINDUS INDICA (TAMARIND) SEEDS
}

\author{
MM Hasan, SA Rahman and MS Akhter* \\ Biotechnology and Genetic Engineering Discipline, Khulna University, Khulna, Bangladesh
}

\begin{abstract}
The crude ethanol and methanol extracts of Tamarindus indica seeds have been investigated to evaluate their antibacterial and cytotoxic potentialities. Extracts were screened for their antibacterial activity against both gram positive and negative bacteria primarily by disc diffusion method and then minimum inhibitory concentration (MIC) assay. Besides the cytotoxic activity were screened by using brine shrimp lethality bioassay. The average zone of inhibition for ethanol extract of seeds of tamarind was ranged from $7.5-13.5 \mathrm{~mm}$ for $500 \mu \mathrm{g} / \mathrm{disc}$. And for methanol extract the zone of inhibition was ranged from $6.5-13.25 \mathrm{~mm}$ for $500 \mu \mathrm{g} /$ disc. From MIC assay minimum inhibitory concentration was found $1.25 \mathrm{mg} / \mathrm{ml}$ for ethanol and $0.625 \mathrm{mg} / \mathrm{ml}$ for methanol extract. The minimum bactericidal concentration was found $2.5 \mathrm{mg} / \mathrm{ml}$ for ethanol and $1.25 \mathrm{mg} / \mathrm{ml}$ for methanol extract. Compared to vincristine sulfate (with $\mathrm{LC}_{50}$ of $0.99 \mu \mathrm{g} / \mathrm{ml}$ ) both ethanol and methanol extract of $T$. indica seeds showed toxicity lower than $100 \mu \mathrm{g} / \mathrm{ml}$ and greater than $30 \mu \mathrm{g} / \mathrm{ml}$. The study confirms greater antibacterial activity of $T$. indica seed extracts with moderate cytotoxic activity. This study thus demands isolation of active principles and thorough bioassays.
\end{abstract}

Key words: Antibacterial activity, Brine shrimp, Lethality bioassay, Phytochemicals, Seeds

\section{Introduction}

Tamarind (Tamarindus indica L.) of the Fabaceae kingdom, subfamily Caesalpinioideae, grows in tropical and subtropical regions and now is one of the most important plant resources as food materials (De Caluwé et al. 2009). It is an ornamental tree and is used inmaking drinks because of its acidic fruits and is a component of many decoctions used as health remedies (Doughari 2006). It is a multipurpose tree because almost all parts have at least some use (Kumar and Bhattacharya 2008). T. indica has various properties and every part of this plant have various uses. It has antioxidant, antimicrobial, cytotoxic, anti-inflammatory, antinematodal, anti-diabetic activity (De Caluwé et al. 2009). Traditionally tamarind has been used by folk medicinal practitioners for the remedy of various diseases. Tamarind preparations are recognized as refrigerants for fevers, and as laxatives and carminatives alone, or in combination with lime juice, honey, milk, dates, spices or camphor (Morton 1987). The powdered seeds are made into a paste for drawing boils and, with or without cumin seeds and palm sugar, are prescribed for chronic diarrhea and dysentery (Morton 1987). Bark is used as a tonic and in lotions or poultices to relieve sores, ulcers, boils and rashes (El-Siddig 2006).

There are various methods to determine in vitro antibacterial activity e.g. disc diffusion, broth dilution and agar dilution method etc (Rahman and Akhter 2018). For primary determination of antibacterial activity agar disc diffusion assay (Bauer 1996) is mostly preferred due to its easy setup, low cost. For supporting and establishing the results obtained from disc diffusion assay, MIC (Minimum Inhibitory Concentration) assay

*Author for correspondence: shamim11akhter@gmail.com 
can also be performed in vitro. Cytotoxicity of a sample can be determined by 'brine shrimp lethality' assay (Michael 1956, Manilal et al. 2009) which has a good correlation with cytotoxic activity on tumors in human body (Meyer et al. 1982). The objective of this study was to identify antibacterial and cytotoxic activity of seeds of Tamarindus indica $\mathrm{L}$.

\section{Materials and Methods}

Collection of samples: Seeds of tamarinds were collected from Daulatpur seed markets, Khulna, Bangladesh.

\section{Preparation of samples}

Seeds were first dried under sunlight with shades for 10 days. Then seeds were smashed and crushed into powder by using a grinder. For solvent extraction $50 \mathrm{~g}$ of powder sample were taken and soaked into $100 \mathrm{ml}$ of $50 \%$ ethanol and another $50 \mathrm{~g}$ were soaked in absolute methanol. Contents were then kept in water bath at $50^{\circ} \mathrm{C}$ for $2 \mathrm{hr}$. The contents were kept out for a while for cooling down. The contents were filtered through Whatman 1 filter paper. The filtrates obtained were evaporated by rotary evaporator and then air dried. The air dried extracts were weighted and $3 \mathrm{gm}$ of tamarind seed extracts were obtained from ethanol and $2.7 \mathrm{~g}$ from methanol extraction. The crude extracts were then kept into refrigerator at $4^{\circ} \mathrm{C}$ for further experiments.

\section{Antibacterial screening \\ Agar disc diffusion assay}

In antibacterial screening of crude extracts, agar disc diffusion method was used. Five pathogenic bacteria strain including four gram negative and gram positive bacteria were chosen for testing. Sterile filter paper disc of $5 \mathrm{~mm}$ were impregnated with $500 \mu \mathrm{g}$ of the test substances and dried under aseptic condition to evaporate residual solvent. Standard ciprofloxacin $(30 \mu \mathrm{g} / \mathrm{disc})$ were used as positive control and blank discs were used as negative control. The sample discs, antibiotic discs, negative control discs were gently placed on to nutrient agar plate which was pre-inoculated with test bacteria. The plates were inversely kept in an incubator at $37^{\circ} \mathrm{C}$ for $24 \mathrm{hrs}$. The antibacterial activity was determined by measuring the diameter of zone of inhibition as describe by Wilkinson 2006.

\section{Minimum inhibitory concentration assay}

For validating the results obtained agar disc diffusion assay, minimum inhibitory concentration assay was performed by using the Resazurin 96 well microtitre plates based in vitro antimicrobial assay methods described by Sarker et al. (2007) and Sarker et al. (2017).

\section{Minimum bactericidal concentration assay}

The minimum bactericidal concentration (MBC) i.e. the lowest concentration of an antibacterial agent required to kill a particular bacterium was determined from broth dilution minimum inhibitory concentration (MIC) tests by sub culturing to agar plates that do not contain the test agent. The MBC was identified by determining the lowest concentration of antibacterial agent that reduces the viability of the initial bacterial inoculum by $\geq 99.9 \%$.

\section{Cytotoxic activity testing}

The brine shrimp lethality test was used to predict the presence of cytotoxic activity in the extracts following the method of Meyer et al. (1982). A graph of \% mortality and log concentration was plotted and median lethal concentration ( $\left.L C_{50}\right)$ was calculated by using MS Office 2016. Test of ethanol and methanol extracts were done in triplicate to get a reliable result. 


\section{Results and Discussion}

Agar disc diffusion assay exhibited that ethanol extract of seeds of Tamarindus indica produced/gave maximum zone of inhibition against Staphylococcus aureus $(13.50 \pm 0.71 \mathrm{~mm})$. For methanol extract the maximum zone of inhibition was found against Proteus vulgaris $(13.25 \pm 0.42 \mathrm{~mm})$ and all other results have been presented in Table 1. Zone of inhibition found less than $8 \mathrm{~mm}$ was rejected as it was considered that the tested compound was not active against such bacteria (Bhalodia and Shukla 2011).

Minimum inhibitory concentration assay was performed against those bacteria for which zone of inhibition was found more than 8 millimeter. The best result obtained from MIC for ethanol extract was against Staphylococcus aureus $(1.25 \mathrm{mg} / \mathrm{ml})$ and for methanol extract it was against Proteus vulgaris $(0.625 \mathrm{mg} / \mathrm{ml})$ (Table 2). For ethanol extract minimum bactericidal concentration (MBC) found for Staphylococcus aureus was $2.5 \mathrm{mg} / \mathrm{ml}$ and for methanol extract minimum bactericidal concentration for Proteus vulgaris was 1.25 $\mathrm{mg} / \mathrm{ml}$. All other results were presented in Table 3. Brine shrimp lethality tests results (Table 4) showed that both the extracts had moderate toxicity to brine shrimp as the $\mathrm{LC}_{50}$ values were below $100 \mu \mathrm{g} / \mathrm{ml}$ and over 30 $\mu \mathrm{g} / \mathrm{ml}$. The $\mathrm{LC}_{50}$ values were $61.025 \mu \mathrm{g} / \mathrm{ml}$ for ethanol extract (Fig. 1) and $44.825 \mu \mathrm{g} / \mathrm{ml}$ for methanol extract (Fig. 2), respectively. For positive control, the $\mathrm{LC}_{50}$ value was $0.99 \mu \mathrm{g} / \mathrm{ml}$.

Table 1. Agar disc diffusion methods for antimicrobial activity assay of tamarind seed extracts

\begin{tabular}{lcc|cc}
\hline \multirow{2}{*}{ Microorganisms } & \multicolumn{4}{c}{ Zone of Inhibition in mm diameter } \\
\cline { 2 - 5 } & $\begin{array}{c}\mathrm{EtOH} \\
(500 \mu \mathrm{g} / \mathrm{disc})\end{array}$ & $\begin{array}{c}\text { Positive control } \\
(30 \mu \mathrm{g} / \mathrm{disc})\end{array}$ & $\begin{array}{c}\mathrm{MeOH} \\
(500 \mu \mathrm{g} / \mathrm{disc})\end{array}$ & $\begin{array}{c}\text { Positive control } \\
(30 \mu \mathrm{g} / \mathrm{disc})\end{array}$ \\
\hline Pseudomonas aeruginosa & $11.50 \pm 0.25$ & $32 \pm 0.5$ & $10.50 \pm 0.13$ & $31.5 \pm 0.13$ \\
Proteus vulgaris & $11.5 \pm 0.36$ & $34 \pm 0.0$ & $13.25 \pm 0.02$ & $31.5 \pm 0.10$ \\
Escherichia coli & $11.75 \pm 0.36$ & $34.25 \pm 0.25$ & $9 \pm 0.75$ & $33.75 \pm 0.75$ \\
Salmonella typhi & $7.5 \pm 0.25$ & $32.50 \pm 0.36$ & $6.5 \pm 0.10$ & $32.75 \pm 0.45$ \\
Staphylococcus aureus & $13.5 \pm 0.71$ & $35.59 \pm 0.36$ & $11.75 \pm 0.25$ & $30.5 \pm 0.36$ \\
\hline
\end{tabular}

Table 2. Minimum inhibitory concentration assay of tamarind crude seed extracts

\begin{tabular}{lccc}
\hline Microorganisms & $\begin{array}{c}\text { Ethanol extract } \\
(\mathrm{mg} / \mathrm{ml})\end{array}$ & $\begin{array}{c}\text { Methanol extract } \\
(\mathrm{mg} / \mathrm{ml})\end{array}$ & $\begin{array}{c}\text { Positive control } \\
(\mathrm{mg} / \mathrm{ml})\end{array}$ \\
\hline Staphylococcus aureus & 1.25 & 1.25 & 0.00098 \\
Pseudomonas aeruginosa & 5.0 & 5.0 & 0.00049 \\
Escherichia coli & 5.0 & 2.5 & 0.00098 \\
Proteus vulgaris & 2.5 & 0.625 & 0.00013 \\
\hline
\end{tabular}


Table 3. Minimum bactericidal concentration determination of tamarind crude seed extracts

\begin{tabular}{ccc}
\hline Microorganisms & $\begin{array}{c}\text { Ethanol extract } \\
(\mathrm{mg} / \mathrm{ml})\end{array}$ & $\begin{array}{c}\text { Methanol extract } \\
(\mathrm{mg} / \mathrm{ml})\end{array}$ \\
\hline Staphylococcus aureus & 2.5 & 2.5 \\
Pseudomonas aeruginosa & - & 5.0 \\
Escherichia coli & 5.0 & 5.0 \\
Proteus vulgaris & 2.5 & 1.25 \\
\hline
\end{tabular}

Table 4. Effect of ethanol and methanol extract of tamarind seeds on brine shrimp

\begin{tabular}{cccccc}
\hline $\begin{array}{c}\text { Concentration } \\
(\mu \mathrm{g} / \mathrm{ml})\end{array}$ & Log C & $\begin{array}{c}\text { Mortality \% of } \\
\text { ethanol extract }\end{array}$ & $\begin{array}{c}\mathrm{LC} 50 \\
(\mu \mathrm{g} / \mathrm{ml})\end{array}$ & $\begin{array}{c}\text { Mortality \% of } \\
\text { methanol } \\
\text { extract }\end{array}$ & $\begin{array}{c}\mathrm{LC} \mathrm{C}_{50} \\
(\mu \mathrm{g} / \mathrm{ml})\end{array}$ \\
\hline 2.5 & 0.39 & 15 & & 15 \\
5.0 & 0.7 & 20 & & 15 \\
10 & 1.0 & 25 & 61.025 & 20 \\
20 & 1.3 & 35 & & 25 \\
40 & 1.6 & 40 & 35 \\
80 & 1.9 & 55 & 50 \\
160 & 2.2 & 65 & 65 & \\
\hline
\end{tabular}

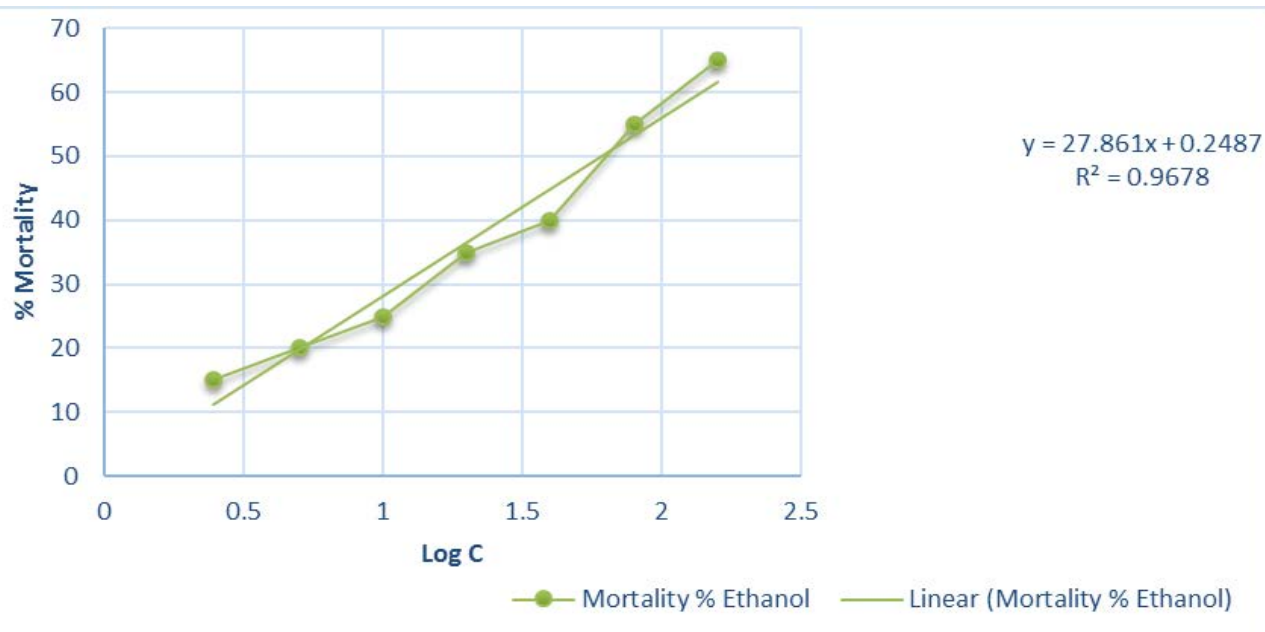

Fig. 1. Plot of log concentration of ethanol extract of tamarind seeds vs. percent shrimp mortality. 


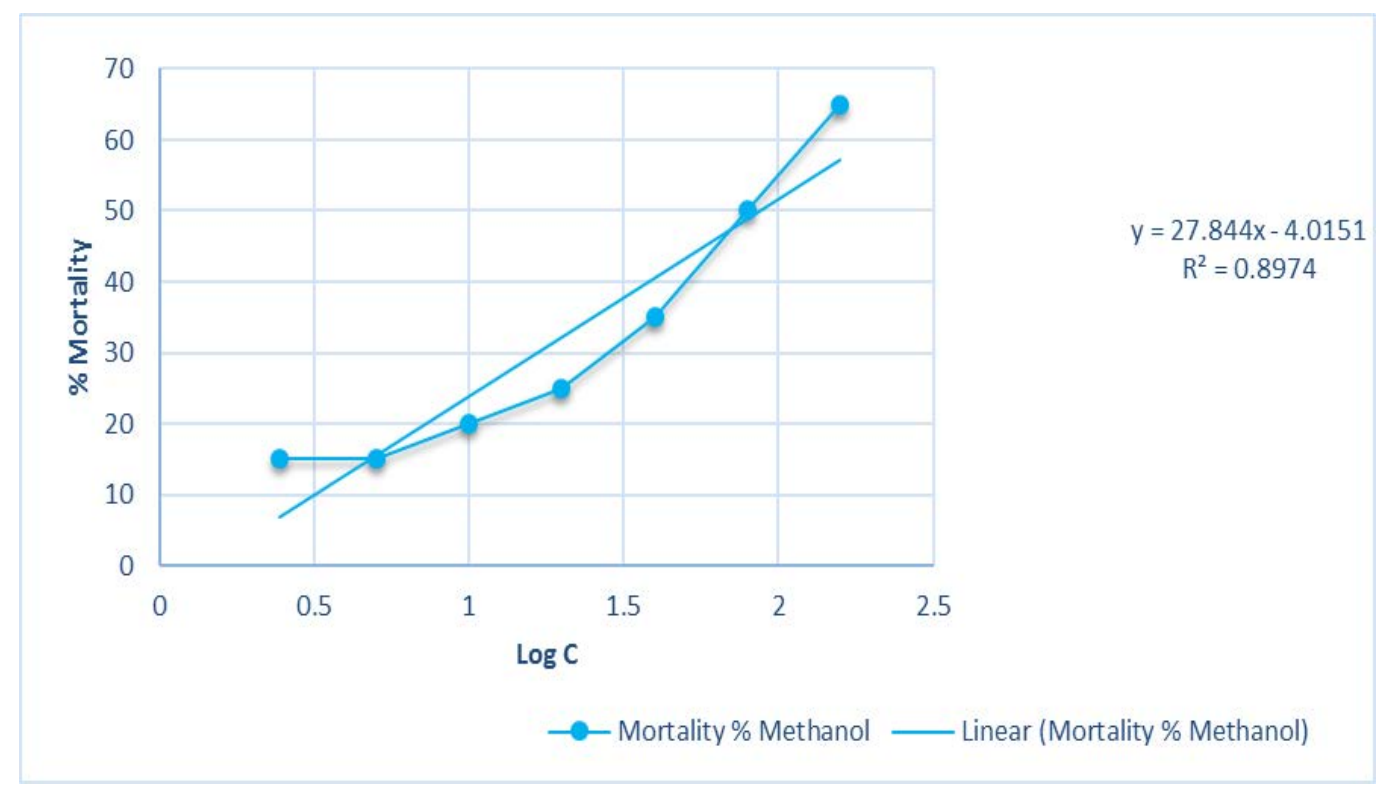

Fig. 2. Plot of log concentration of methanol extract of tamarind seeds vs. percent shrimp mortality.

In conclusion in the current study it was found that the ethanol extract of the seeds of $T$. indica exhibited promising activity against Staphylococcus aureus. Again the methanol extract also showed an accountable antibacterial activity against $P$. vulgaris. Both type of extracts of seeds of Tamarind showed moderate cytotoxicity to Artemia salina which could be an indication of presence of active anti-cancer compound in the seeds. The antibacterial screening in this study supports the traditional medicinal practices of this plant. Another part of this study was to investigate cytotoxic potentialities of seeds of tamarind. The result obtained suggests that it has potent cytotoxic activity. The antibacterial and cytotoxic activity of tamarind seed extracts suggests further isolation of active ingredients through bioassays. In vivo trials would help to sort out active compounds of the seed as pharmaceutical and therapeutic agents.

\section{References}

Bauer AW (1996). Antibiotic susceptibility testing by a standardized single disc method. American Journal of Clinical Pathology, 45: 149-158.

Bhalodia NR and Shukla VJ (2011). Antibacterial and antifungal activities from leaf extracts of Cassia fistula. An Ethnomedicinal Plant Journal of Advanced Pharmaceutical Technology and Research, 2(2): 104.

De Caluwé E, Halamová $\mathrm{K}$ and Van Damme $\mathrm{P}$ (2009). Tamarind (Tamarindus indica L.): a review of traditional uses, photochemistry and pharmacology. In African natural plant products: discoveries and challenges in chemistry and quality. American Chemical Soc., 1021: 85-110.

Doughari JH (2006). Antimicrobial activity of Tamarindus indica Linn. Tropical Journal of Pharmaceutical Research, 5(2): 597-603.

El-Siddig K (2006). Tamarind: Tamarindus indica L. Crops for the Future, 1: 1-88. 
Kumar CS and Bhattacharya S (2008). Tamarind seed: properties, processing and utilization. Critical Reviews in Food Science and Nutrition, 48(1): 1-20.

Manilal A, Sujith S, Kiran GS, Selvin J and Shakir C (2009). Cytotoxic potentials of red alga, Laurencia brandenii collected from the Indian coast. Global Journal of Pharmacology, 3(2): 90-94.

Meyer BN, Ferrigni NR, Putnam JE, Jacobsen, LB, Nichols DE and McLaughlin JL (1982). Brine shrimp: a convenient general bioassay for active plant constituents. Planta Medica, 45(5): 31-34.

Michael AS, Thompson CG and Abramovitz M (1956). Artemia salina as a test organism for bioassay. Science, 123(3194): 464.

Morton JF (1987). Tamarind. Fruits of the warm climates. Miami, FL, pp. 33-189.

Rahman SA and Akhter MS (2018). Antibacterial and cytotoxic activity of seeds of white hyacinth bean (Lablab purpureus L. sweet 'white'). Journal of Advances in Biotechnology and Experimental Therapeutics, 1(2): 49-54.

Sarker SD, Nahar L and Kumarasamy $Y$ (2007). Microtitre plate-based antibacterial assay incorporating resazurin as an indicator of cell growth, and its application in the in vitro antibacterial screening of phytochemicals. Methods, 42: 321-324.

Sarker SD, Nahar L, Nurunnabi TR, Rahman SMM, Sohrab MH, Billah MM and Sharples GP (2017). A mini-review on oxysporone. Trends in Phytochemical Research, 1: 55-60.

Wilkinson JM (2006). Methods for testing the antimicrobial activity of extracts. Modern Phytomedicine. Turning Medicinal Plants into Drugs, $8^{\text {th }}$ Ed., John Wily and Sons, Germany, pp.157-171.

(Manuscript received on May 05, 2018 and revised on September 11, 2018) 